\title{
Analysis of accident in Indonesian construction projects
}

\author{
Toriq Ghuzdewan ${ }^{1, *}$ and Petrus Damanik ${ }^{1}$ \\ ${ }^{1}$ Civil and Environmental Engineering Department, University of Gadjah Mada, Yogyakarta, Indonesia
}

\begin{abstract}
The numbers of accidents in construction projects in Indonesia is the highest in the industries as mentioned by the Ministry of Manpower and Transmigration's publication. Construction accidents are often reported in the media such as televisions, newspapers, magazines, and the internet. This study employs construction accident data from the internet, from the year 2012 to 2014 using search engines with keywords such as construction work accident, falling from height, an accident from falling objects, electrical shock, etc. The data are then analyzed to understand the types, causes and impacts of accidents and suggestion for future improvement. The results showed that of the 332 data obtained, accidents in building projects are the highest $(47 \%)$, followed by that in housings ( $42 \%)$ and others $(11 \%)$. According to the types of accidents, electrical shock is the highest (115 cases), followed by falling from height (91 cases) and stricken by objects ( 83 cases). The causes of accident due to unsafe acts was $61 \%$ and unsafe condition was $39 \%$. Most of the accidents can be categorized as fatal $(68 \%)$, serious $(16 \%)$ and catastrophic (14\%). It is recommended that administrative action and Personal Protective Equipment (PPE) should be applied to reduce the risk of accident.
\end{abstract}

\section{Background}

Accidents in construction projects in Indonesia recently received serious attention as the high number of accidents occurred in several prestigious projects. In 2018 there were at least eight serious accidents such as the collapse of supports on the Light Rail Transit project in Palembang, the collapse of bridge at the Bocimi toll road project, the collapse of girder at the Pasuruan toll road project, etc. [1]. Safety policy actually has been regulated since quite long time ago as set in law number 1-year 1970 on employment, Minister of Manpower and Transmigration's regulation number 1 year 1980 on Occupational Safety and Health on Building Construction, Minister of Public Work's regulation number 5/2014 on Guidelines for Occupational Safety and Health Management System for Construction of Public Works, etc. Nevertheless, performance on construction safety seems unsatisfactory as can be seen from many accidents occurred in construction projects until nowadays.

The Ministry of Manpower and Transmigration in 2010 reported that work accident in the construction sector was the highest $(31.9 \%)$, followed by that in manufacturing industry $(31.6 \%)$, transportation $(9.3 \%)$, mining $(2.6 \%)$, forestry $(3.8 \%)$, and other sectors $(20 \%)$. This high number indicates that the problem on safety in construction should obtain serious attention. In the future, it is even more important since construction projects in Indonesia are projected to increase significantly. Construction projects have an important role in the national development with growth estimated at $10 \%$ to $15 \%$ per year. The value of project increased from about 320 trillion Rupiah in 2010 to 696 trillion Rupiah in 2016 [2]. Construction in Indonesia characterised to employ a large number of workers, although it is now commencing to use technology. However, the use of new technology also increases the risk of accidents as being unfamiliar with the application of new technology.

Construction projects have considerable risks due to their specific characters, such as each project is unique, hard workplace environment, projects are moving from one location to another location, employing large numbers of workers which also are temporary, working with machine where many of them are electrical or heavy equipment. These characters may pose increasing risk and more serious danger.

Accidents often obtain attention for news coverage, as well as construction accidents which are often reported on TVs, newspapers, magazines and other medias such as the internet. By "googling" with keywords such as "construction work accident" for example, many accident reports can be acquired. This research aims to obtain accident data from the internet. The study was conducted in 2014 collecting last three

* Corresponding author: toriq@ugm.ac.id 
years data, i.e. from 2012 to 2014. From the data, it can be analysed to obtain the types of accidents, causes of accidents, the severity and suggestions for future prevention. It is expected that lesson learned can be obtained from accidents events as reported in the news. Understanding about various kinds of construction accidents, their causes, their impacts and suggestions for improvement is important for better future safety management.

\section{Research Problem}

Accidents in construction projects in Indonesia is quite high, even the highest in the industries. Many construction accidents are reported in media such as on television, newspapers, the internet, and other media. This research will examine construction accidents which were reported on the internet, to identify what kinds of accidents were happened in the field of construction projects, why or how they happened, what are their impacts, and what suggestions for preventions obtained from the reports.

\section{Aim of The Research}

The purpose of this study is to collect data from the internet regarding construction accident to identify types, causes, and impacts or severity of accidents and to explore suggestion for prevention in the future. It is expected that a lesson learned can be drawn for better safety management in the future.

\section{Literature Review}

\subsection{Construction Project}

Construction project is a work process on the creation of building or infrastructure. Building projects usually can be classified into high rise building and housing. While infrastructure where also often called civil works can be divided into roads, bridges, airports, docks, dams, irrigation, etc. Construction project also may consist of creating new buildings or maintenance/ renovation existing buildings. The characters of construction project are different from that of manufacturing industries. Manufacturing industries produce goods in large quantities, repeatedly in one place, while construction projects are unique, one-off and performed at different locations. A construction project therefore generally begins with planning, execution, and monitoring/controlling processes.

Construction is also a high-risk work, caused by its characters as mentioned above and also the nature of its work which consists of large numbers of jobs, difficult tasks, hardworking-conditions (as caused by nature, weather, etc.), employing mass labor, using equipment (electric and heavy equipment), etc. Construction project also involves many stakeholders, such as owners, contractors, consultants, sub-contractors, suppliers, manpower, etc. These different stakeholders may have different interests which may pose conflict. Owners usually want lower project costs, while contractors prefer to create higher profits. The low budget of the project often causes safety program to be sacrificed. A large number of parties involved may also increase risk of safety programs.

There are indications that safety performance in construction projects in Indonesia is still low as can be seen from a large number of work accidents. Accidents that frequently happened in construction projects include electrical shock, hit by falling object and fall [3]. Most of these accidents were caused by the carelessness of the workers, unsafe construction and inadequate PPE. Problems related to the low use of appropriate PPE was also exposed by another researcher [4]. Lack of worker training, worker attitudes, and management procedures contribute to safety program [5]. Unsafe act and unsafe condition are still commonly found in construction projects. It is believed that organizational and managerial issues are the weakness of the safety management system [6]. Safety management system should be implemented to improve safety performance. This system can be started in planning, organizing, implementing and monitoring. It should be viewed from human components, materials, money, machinery/ tools, working methods, and information [7]. Safety management system and safety planning, therefore, are very important to reduce risk [8].

\subsection{Literature on Work Accident}

Workplace accidents can be defined as uncontrolled and unplanned adverse events, which can be caused by human factors, circumstances or environments, and can result in injury, illness, death or damage to work property [9]. Accidents are certainly not to be expected as it causes harm or loss. No one wants an accident and therefore an effort to prevent accidents is very important. Understanding the causes of accidents are useful to be more careful and for preventing similar accidents in the future [10].

Work accidents can be classified into several types. The International Labour Organization (ILO) classified accidents by types, causes and nature of injuries [10]. Types of accidents include falling from height, hit by falling objects, caught in between, over-capacity, hightemperature exposure, electrical shock, contact with hazardous materials or radiation, etc. Causes of accidents include employing transportation/ handling vehicle, lifting equipment, other mechanical equipment, materials and radiation, work environment, animals. Nature of injury can be in the form of fracture, dislocation or sprain, muscle or muscle strain, bruises, and other internal injuries, amputations, surface wounds, concussions and crushing, burns, poisoning, due to weather, suffocation, electric current effects, radiation. Classification according to the position of injuries can be on the head, neck, body, parts of upper/ lower body, and common abnormalities.

There are several occupational accident theories. One of the earliest is Heinrich's domino theory [11]. It 
explains that an accident occurs as a result of a series of events, where these events are likened to dominoes. The dominos represent events such as injury, accident, unsafe condition, the fault of person and social environment. As domino metaphor that if one domino falls will trigger other dominos to fall. Heinrich said that the cause of occupational accidents is largely due to the unsafe act $(88 \%), 10 \%$ caused by unsafe condition and $2 \%$ is unprevenTable cause. In his theory, Heinrich argues that unsafe actions and unsafe conditions occur because people make mistake.

Bird and Germain (1985) modified the Henrich's model and emphasized the importance of management's role to prevent accidents [11]. Bird and Germain named the model as the Loss Causation Model as shown in Figure 1. Loss can be in the form of injury or human casualties, property losses and work process disruptions, such as delayed or termination of project. Loss occurs because of several causes in series, i.e. incidents, immediate cause, basic causes and lack of control. In accident analysis, the root causes of the problem should be found, i.e. lack of control either because of inadequate program, inadequate standard, or inadequate compliance.

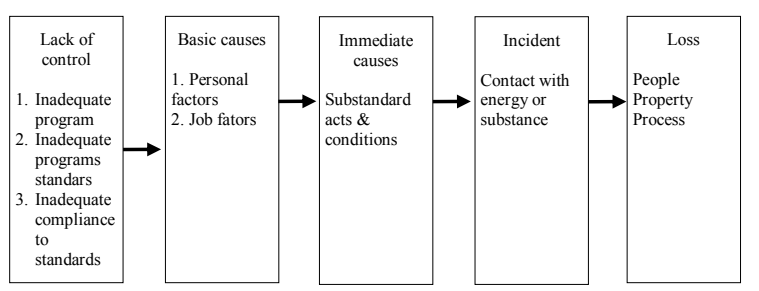

Fig. 1. The Loss Causation Model

\subsection{The Impact of Accidents}

The impact of accident relates to level of severity. According to Department of Occupational Safety and Health Malaysia (2008), the level of severity of an accident can be classified into five categories as shown in Table 1 [12]. Negligible is the lowest level that is an accident which only causes minor abrasion or bruises. Minor is an accident which caused injury but not permanently. Serious is an accident that causes permanent disability but does not cause death. Fatal is an accident that causes death of one person. While catastrophic, the highest level is an accident that causes more than one people died and/or excessive property damage.

Table 1. Severity of Accidents

\begin{tabular}{|l|l|}
\hline Severity & Description \\
\hline Catastrophic & $\begin{array}{l}\text { Numerous fatalities, irrecoverable } \\
\text { property damage }\end{array}$ \\
\hline Fatal & $\begin{array}{l}\text { One single-fatality, major property } \\
\text { damage }\end{array}$ \\
\hline Serious & Non-fatal injury, permanent disability \\
\hline Minor & Disabling but not permanent injury \\
\hline Negligible & $\begin{array}{l}\text { Minor abrasions, bruises, cuts, first aid } \\
\text { type injury }\end{array}$ \\
\hline
\end{tabular}

\subsection{Risk Control}

Risk control is an attempt to reduce or eliminate the potential hazards that may pose risk of occupational injury. According to OHSAS 18001:2007, there are hierarchies of hazard control measures, i.e. (1) elimination, (2) substitution, (3) engineering/ design control, (4) administrative control, and (5) use of personal protective equipment (PPE) [13]. The first three levels are the most desirable, yet often impracticable. For example, elimination is the most reliable and effective method for eliminating source of danger, but it is often not possible because it requires a very expensive cost.

\subsection{Safety Management System}

Safety management system (SMS) has been governed by the Minister of Manpower Regulation number 5 year 1996 and Minister of Public Works Regulation number 9 year 2008 with the purpose to prevent work accidents. In general, SMS consist of a circular process of management from commitment, planning, implementation, evaluation, management review and continuous improvement. In SMS, hazard identification, risk assessment and risk control must be undertaken, usually called HIRARC (Hazard Identification, Risk Assessment and Risk Control) as shown in Table 2. When initiating a project, risk identification should be conducted to identify any potential risk which may occur. Each risk is assessed to recognize the level of risk and the anticipated action. Recognizing potential hazards and anticipatory measures are very important in preventing accident.

Table 2. HIRARC

\begin{tabular}{|l|l|l|}
\hline Risk Identified & Risk Assessment & Risk Control \\
\hline Fall from height & Serious/ fatal & $\begin{array}{l}\text { Fence, safety } \\
\text { harness }\end{array}$ \\
\hline
\end{tabular}

\section{Research Methodology}

This research employs secondary data, i.e. from news on the internet. Using search engines "Google" with keywords such as construction work accident, falling from height, stricken, electrical shock, buried and other keywords associated with construction accident.

The data obtained are analyzed to identify the description, location, type, cause, impact, severity, and time of the accident. Location refers to types of project, whether it is in building, housing, or civil works (roads, bridges, irrigation, etc.) projects. Causes of accidents are grouped into unsafe act and unsafe condition. Impacts of accidents are grouped into minor, serious, fatal and catastrophic categories. The data are presented on bar diagrams to depict the number of occurrences.

\section{Analysis and Result}

As explained in the methodology, this study based on secondary data. Secondary data are data obtained from existing sources, such as company documentation, publications, industry analysis, internet, etc. [14]. This study uses secondary data from the internet, using 
"google" and keywords such as construction accident, falling, stricken, electrical shock, buried, etc. There are more than 60 websites such as tribunnews.com, republika.co.id, merdeka.com, etc. obtained that provide data required.

In searching the data, it was filtered into the last three years, i.e. from 2012 to 2014 and 332 construction accidents data was obtained. These data are about $21.4 \%$ of work accidents according to Jamsostek's report in 2010. The data obtained then are grouped into categories according to locations, types, causes, and impacts of accident and from the data it is also reviewed what suggestions are recommended.

From the data, it was found that the numbers of accidents were increasing from 2012 to 2014 (Figure 2). Most of the accidents were in building and housing projects. There were 52 accidents in average in each year in building projects, 46 in housing projects and 12 in other projects. From the data, accidents in civil works were much less compare to that in buildings, however, this finding needs further investigation since perhaps accidents in civil projects had been missed from news coverages.

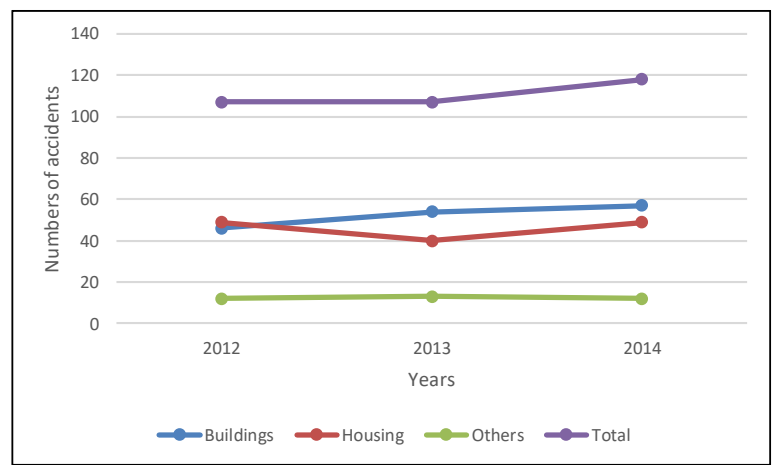

Fig. 2. Numbers of Accidents

\subsection{Types of Accidents}

Figure 3 shows the numbers of accidents by types. Most accidents were electrical shock, fell and stroked by objects. Electrical shock mostly happened because materials or devices were in contact with electricity or it happened because part of bodied touched a peeled electrical cable. Fell from height occurred were in building projects, i.e. fell from $2^{\text {nd }}$ and $22^{\text {nd }}$ floor, besides there were also fall from tower, stairs, scaffold, roof, etc. Fall of objects due to falling rocks, collapsed wall, collapsed concrete columns, collapsed steel structures, fences, roof, etc. These types of accident occurred in building project, in line with the findings in which most of the accidents occurred were in building projects. Other accidents such as buried in soils, stuck in hole/ digging, hit, punctured, pinched, beaten, burned or poisoned are also found but in relatively small numbers.

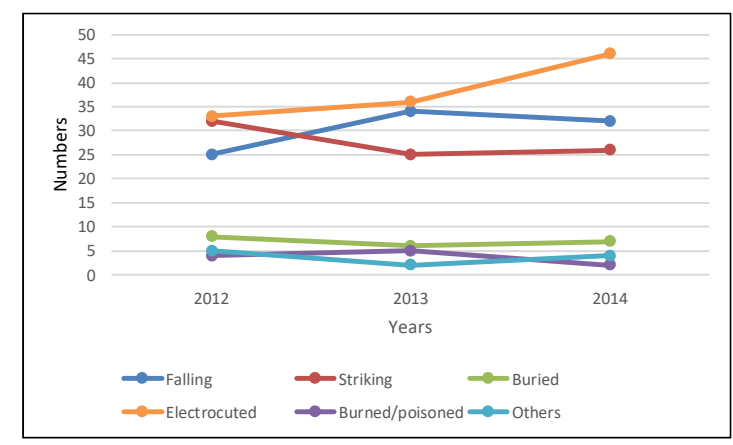

Fig. 3. Types of Accidents

\subsection{The Impacts of Work Accidents}

The impacts of accidents might relate to injury on human, property damaged, process disruption, poor quality and environmental disturbances. From the data, most accidents caused injury or casualties. Reports on property damaged, process disruption, poor quality and environmental disturbances were only few. Based on severity criteria, Figure 4 shows that most accidents were fatal. There were 223 fatal, 54 serious, 46 catastrophic, 5 minor and 2 negligible accidents. Fatal accident was death of one person. Serious accidents included serious head injury, fracture, burn, and poisoning. Catastrophic accidents are that cause more than one person died and damaged equipment/property in quite a large scale. While minor accidents included wounds on hand/ foot and unconscious. The data shows that fatal accidents were increasing from 2012 to 2014 .

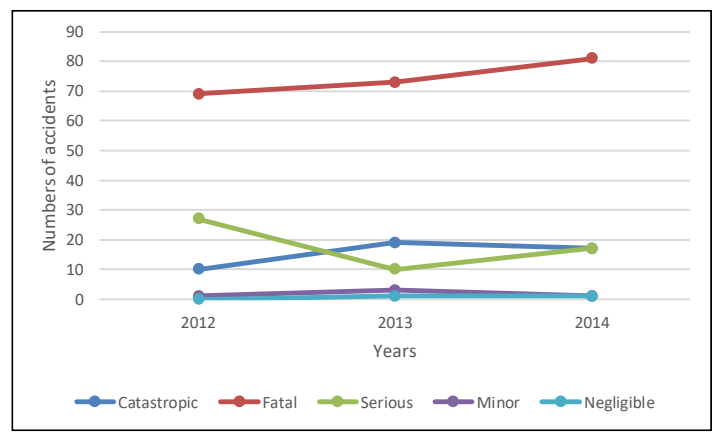

Fig. 4. Severity of the accidents

\subsection{Causes of Work Accident}

As can be seen from Figure 5 that based on criteria from Bird and Germain (1990) most of the accidents were caused by unsafe act. In total $61 \%$ of the accidents were caused by unsafe act, and $39 \%$ were caused by unsafe conditions. Including unsafe acts are such as careless, incompetent workers, drowsy, negligent, oblivious, inappropriate PPE, non-standard working methods, insufficient mounting buffers, and lack of supervision. Including unsafe conditions are such as working near slopes of excavation, working on span of bridges over rivers, working on slippery workplaces, working near power lines, working on wrecked or inappropriate equipment, unsTable building structure, unsTable supported, broken cables, and fragile building's components. 


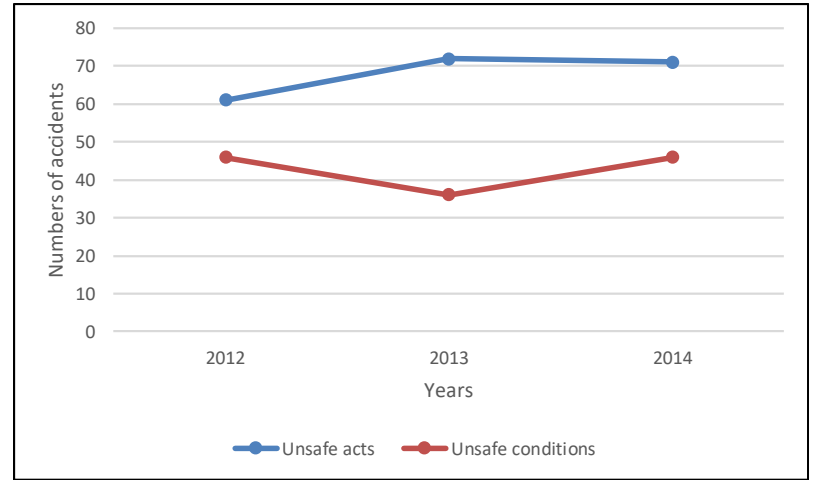

Fig. 5. Causes of Accidents

\subsection{Time of Accident}

The data also report the time of the accident. Figure 6 shows that most of the accidents occur in the afternoon and in the morning. There were 91 accidents in the morning, 96 in the afternoon, 47 in the evening and 18 at night. This is quite interesting since usually it is believed that most accidents occur near the end of work hour when workers are tired, lack of concentration or they are in rush for going home. From the data, caution in the morning and in the afternoon need to obtain more attention for preventing accidents. Work accidents at night were only few, but this may be because not much works were done at night or there was only little overtime.

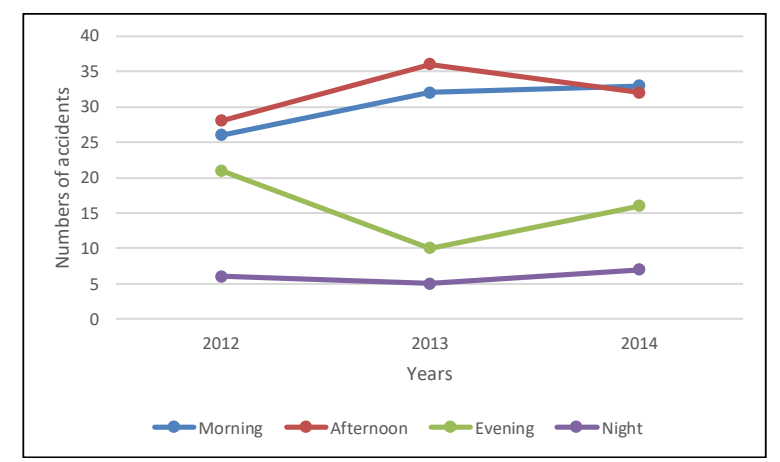

Fig. 6. Time of Accidents

\subsection{Risk Control}

From the news reports, there were also often reported suggestions about what needed to be done to prevent the accidents. Some of these suggestions can be grouped as administrative measure (64\%) and use of PPE (36\%). Recommended administrative actions include better supervision, better selection of workers, working with co-workers, shifts working, rewards and punishment, and housekeeping. Important PPE include safety harness, signages, guardrails, border on the edge of openings and safety helmet. This is in line with the findings of another research [8] that such factors are necessary for preventing accident as (a) full-time safety supervisor, (b) use of PPE (c) control over the implementation of safety, (d) training of workers, (e) incentives, and (f) safety culture.
It is also believed that the role of key stakeholders such as owners, consultants, contractors and supervisors are very important to ensure safety program is applied in project. Owner has an important role to facilitate and provide budget for safety programs. Design consultants can create safe design and safe work plans/ procedures. Contractor carries out the project execution according to sound safety program. While supervisor consultant should be able to supervise the implementation of safe work.

\section{Conclusion}

Based on the data collected, it is found that:

a. Most of work accidents were occurred in building projects $(47 \%)$ and housings $(42 \%)$, while in civil works relatively few (11\%). However, it is necessary to consider the possibility of news coverage on civil projects being missed from the media at that time.

b. The most common types of accident were electrical shock, followed by falling from height and hit by falling object. This is in accordance with the results of another research that electrical shock is the most frequent accident occurred [3].

c. Based on the severity of accident, $68 \%$ of accidents were fatal, $19 \%$ were serious and $13 \%$ were catastrophic.

d. Most accidents occurred in the morning and afternoon.

e. $59 \%$ of the causes of accident can be categorized as unsafe acts and $41 \%$ as unsafe conditions.

\section{Recommendation}

a. Research on construction accidents is crucial since the trend of accidents is increasing in high numbers. Moreover, it is found that most of the accidents are fatal, serious and catastrophic. Safety issues need to obtain more attention as project opportunity in the future is increasing and projects are more complex related to new or advanced technology, use of new material, and new methods.

b. This study was conducted in 2014 so it is necessary to be updated. It will be useful to look for longer time interval to obtain more data for better lesson learned. This research found that accidents mostly occurred in building projects, while recently there is indication that there are many accidents in infrastructure/ civil work projects.

c. This study uses data only from the internet. Other media such as magazines, newspapers, research results, government's / institutions' publications, etc. can be observed to enrich data.

d. Construction stakeholders such as the government, owners, contractors, consultants and other stakeholders should raise their awareness on the importance of safety programs and play a more active role in preventing accidents. 


\section{References}

1. M. Sholih, Daftar Kecelakaan Proyek Infrastruktur pada Awal 2018, available from: https://tirto.id/daftar-kecelakaan-proyek infrastruktur -pada-awal-2018-cE4M, (Accessd on 20 May 2018)

2. BPS (Badan Pusat Statistik), Nilai Konstruksi Yang Diselesaikan Menurut Jenis Pekerjaan, available from https://www.bps.go.id/staticTable/2016/10/ 17/918/nilai-konstruksi-yang-diselesaikan-menurutjenis-pekerjaan-juta-rupiah-2004-2016.html, (Accessd on 20 May 2018)

3. B. Hidayat, R. Ferial, dan N. Anggraini, Kecelakaan Kerja Proyek Konstruksi di Indonesia tahun 20052015, Konteks10, (2016)

4. R. Wirahadikusumah, Tantangan Masalah Keselamatan dan Kesehatan Kerja pada Proyek Konstruksi di Indonesia, J Institut Teknologi Bandung, (2005)

5. P. Ryan, Analisis akar masalah unsafe act \& unsafe condition keselamatan dan kesehatan kerja (K3) konstruksi dengan metode 5 whys, Tugas Akhir Tingkat Sarjana Strata 1, Universitas Gadjah Mada, Yogyakarta, (2011)

6. M.R.A. Simanjuntak, R. Praditya, Identifikasi Penyebab Risiko Kecelakaan Kerja Pada Kegiatan Konstruksi Bangunan Gedung DI DKI Jakarta, J I Media Engineering, 2, 2, (2012).

7. B. Endroyo, Peranan Manajemen K3 dalam Pencegehan Kecelakaan Kerja Konstruksi, J III, 1, (2006)

8. B. Endroyo and Tugino, Analisis faktor-faktor penyebab kecelakaan kerja konstruksi, J teknik sipil dan perencanaan, 9, 1, (2007)

9. D. Colling, Industrial Safety, Prentice Hall, (1990), in the OSH Center (2018)

10. Suma'mur, Higiene Perusahaan dan Kesehatan Kerja (HIPERKES). Jakarta: Penerbit CV Sagung Seto, (2009)

11. OHSBOK (OHS Body of Knowledge), Models of Causation: Safety, Safety Institute of Australia Ltd, (2012)

12. Department of Occupational Safety and Health Malaysia, Guidelines for hazard identification, risk assessment and risk control (HIRARC), Putrajaya: Ministry of Human Resources Malaysia, pp. 7-18, available from: http://www.dosh.gov.my/doshv2/ phocadownload/guidelines/ve_gl_hirarc.pdf, (Accessd on 20 May 2008)

13. R. Mahendra, Hierarki Pengendalian Bahaya dalam OHSAS 18001:2007, available from: https://isoindonesiacenter.com/hierarki-pengendalian -bahaya-dalam-ohsas-180012007 (Accessd on 20 May 2018)

14. U. Sekaran, (2011) dalam Syarif, Research Methods for business Edisi I and 2. Jakarta: Salemba Empat. (2018) 